\title{
Comparison of Turkey and Countries with High PISA Achievement in terms of Education Expenditures and Academic Achievements
}

\author{
DOI: $10.26466 /$ opus. 957777
}

$*$

\author{
İlknur Maya* $-\underline{\text { Sedat Yakut }}{ }^{* *}$ \\ * Prof. Dr., Canakkale Onsekiz Mart University, Education Faculty, Canakkale/ Turkey \\ E-Mail: mayailknur@gmail.com ORCID: 0000-0001-9964-1382 \\ ** English Teacher, Canakkale Ibrahim Bodur Anatolian High School, Canakkale/ Turkey \\ E- Mail: yakut.sedat83@gmail.com ORCID: $\quad$ 0000-0002-6492-9439
}

\begin{abstract}
The aim of this research is to compare the education expenditures of the Economic Cooperation and Development Organization (OECD) countries such as Canada, Finland and South Korea, which are successful in the 2018 cycle of the Program for International Student Assessment (PISA) with Turkey, and to make suggestions for Turkey. The research was designed in the scanning model. The research population is 36 OECD countries. Canada, Finland and South Korea which were succeed in the 2018 PISA and Turkey were selected as samples. Data were obtained from OECD reports on the 2018 PISA cycle and other international and national documents. In the research, document analysis method was used. According to the results of the research, it has been seen that the education expenditures of Canada, Finland and South Korea are high and the countries are successful in PISA. Therefore, it can be said that there is a positive relationship between PISA achievement and education expenditures. Public education expenditures only in higher education in Turkey are higher than Canada, Finland and South Korea and the OECD average. Education expenditures per student in Turkey are below the OECD average and almost a third of that of Canada, Finland and South Korea. There are significant differences when comparing Turkey with other countries (Canada, Finland and South Korea) in terms of Gross Domestic Product (GDP), expenditure per student and teachers' salaries.
\end{abstract}

Key Words: Education Expenditures, Achievement, PISA, Turkey. 


\title{
Türkiye ile PISA Başarısı Yüksek Ülkelerin Eğitim Harcamaları ve Akademik Başarıları Yönünden Karşılaştırılması
}

\begin{abstract}
*
Öz

Bu araştırmanın amacı, Türkiye ile Uluslararası Öğrenci Değerlendirme Programı (PISA) 2018 döngüsünde başarılı olan Kanada, Finlandiya ve Güney Kore gibi Ekonomik Kalkınma ve İşbirliği Örgütü (OECD) ülkelerinin eğitim harcamalarının istatistiki yönünden karşllaştırmasın yapmak ve Türkiye açısından öneriler getirmektir. Araştırma, tarama modelinde tasarlanmıştır. Araştırma evreni 36 OECD ülkesi olup, örneklem olarak Türkiye ile 2018 PISA'da başarll olan Kanada, Finlandiya ve Güney Kore seçilmiştir. Veriler, 2018 PISA döngüsüne ilişkin OECD raporları, diğer uluslararası ve ulusal dokümanlardan elde edilmiştir. Araştırmada, doküman analizi yöntemi kullanılmıştır. Araştırma sonuçlarına göre, Kanada, Finlandiya ve Güney Kore ülkelerinin eğitim harcamalarının yüksek ve ülkelerin PISA araştırmasında başarılı olduğu görülmüştür. Bu nedenle, PISA başarısı ile eğitim harcamaları arasında bir pozitif bir ilişki olduğu söylenebilir. Türkiye'de sadece yükseköğretimde kamu eğitim harcamaları, Kanada, Finlandiya ve Güney Kore ülkelerinden ve OECD ortalamasından yüksektir. Türkiye'nin öğrenci başına eğitim harcamaları, OECD ortalamasının altında ve Kanada, Finlandiya ve Güney Kore ülkelerine göre ü̧̈te biri kadardir. Türkiye ile diğer ülkeler (Kanada, Finlandiya ve Güney Kore) Gayri Safi Yurt İçi Hasıla (GSYİH), öğrenci başına harcama ve öğretmen maaşları bakımından karşılaştırıldı̆̆ında önemli farklılıklar bulunmaktadır.
\end{abstract}

Anahtar Kelimeler: Eğitim Harcamaları, Başarı, PISA, Türkiye. 


\section{Introduction}

Education transforms life for the better, ensures peace, tries to eradicate poverty and promotes sustainable development (UNESCO, 2020). Education offers individual contributions to people as well as social contributions to countries. Well-educated people generally have better health and living conditions. They also participate more in civic and political life (Lonescu, Lonescu and Jaba, 2013, p.141). Thanks to education, adaptation to change and development becomes faster and easier (Özen, 2020, p.6439). It is possible to see the benefits of education in many areas such as health, security and justice, decent society, environmental awareness and respect for differences.

Undoubtedly, resources are needed to carry out education services properly that provide positive contributions to many areas of life, from social and cultural developments to raising qualified human resources, from average life expectancy to taxation (Işık, 2019, p.41). The fact that education is a human right above all makes it necessary to see it as a public service. Most of the education expenditures are made through public resources. Therefore, investments in education are expected to show positive results in national and international exams.

The International Education Community reports that they are strongly united to provide inclusive and equitable quality education for children, youth and adults, while promoting lifelong learning opportunities for all. The Community says that it is necessary to work together to achieve educational goals, which will strengthen international cooperation in the world of education. It emphasizes that significant additional financing is needed to achieve these goals and that resources should be used in the most effective way to ensure progress (Education 2030, 2016, p.71). Within the scope of comparative education, education expenditures are examined as well as many elements such as an overview of the education systems of the countries, education management, grading of the education system, teacher training, curriculum and supervision system.

Countries are developing policies to mobilize resources to increase the social and economic expectations of individuals, to provide incentives for more output at school, and to meet increasing demands. It 
plans to increasingly explore international comparisons of these policies with educational opportunities and outcomes (OECD 2019a, p.3). It is understood from this that the importance given to education by countries is increasing day by day. Many countries are curious about the worldwide education rankings and try to participate in international exams such as PISA and TIMSS.

Through international exams, countries can see their current situation and find the opportunity to compare their situation with other countries. In recent years, the International Student Assessment Program (PISA), which has been developed by the Organization for Economic Cooperation and Development (OECD) and applied in many countries at the international level, has come to the fore.

PISA, implemented through the OECD, is an international research conducted cyclically every three years that measures and evaluates the knowledge and skills acquired by 15-year-old students enrolled in formal education in certain areas. It measures 15-year-olds' ability to use three core subjects; reading, mathematics and science knowledge and skills to meet real-life challenges. In the cycle, which takes place every three years, a subject is determined as the major domain of assessment and detailed analyzes are made about that subject. In the PISA research conducted in 2018, the field of reading skills was chosen as the major domain of assessment. The demand for PISA research, which was first applied in 2000, has increased over the years (OECD, 2019b, p.3; PISA 2018 Türkiye Ön Raporu, 2019, p.10, 16). From the beginning, the distribution for the major subjects determined in PISA cycles and the number of participating countries is shown in Table 1.

Table 1. Major Subjects Determined in PISA Cycles and Number of Participating Countries

\begin{tabular}{|c|c|c|c|c|c|c|c|}
\hline $\begin{array}{l}\text { PISA } \\
\text { Cycles } \\
\end{array}$ & PISA 2000 & $\begin{array}{l}\text { PISA } \\
2003 \\
\end{array}$ & $\begin{array}{l}\text { PISA } \\
2006 \\
\end{array}$ & PISA 2009 & $\begin{array}{l}\text { PISA } \\
2012 \\
\end{array}$ & $\begin{array}{l}\text { PISA } \\
2015 \\
\end{array}$ & PISA 2018 \\
\hline Major Subject & Reading & Mathematics & Science & Reading & Mathematics & Science & Reading \\
\hline $\begin{array}{l}\text { Participating } \\
\text { Countries }\end{array}$ & 43 & 41 & 57 & 65 & 65 & 72 & 79 \\
\hline
\end{tabular}

Source: (PISA 2018 Türkiye Ön Raporu, 2019, p.20). 
PISA research included 43 countries in 2000, 41 in 2003, 57 in 2006, 65 in 2009 and 2012, 72 in 2015 and 79 in 2018. In addition, reading skills in 2000 and 2009, mathematical literacy in 2003 and 2012, science literacy in 2006 and 2015, and reading skills in 2018 were determined as the major domain of assessment. It is seen from the table that the number of countries participating in PISA is increasing every year.

It can be said that PISA research results have an important place in the analysis of education services of countries. In this context, comparing countries using comparative educational science in terms of effectiveness and efficiency in educational services can make a positive contribution to the allocation of resources in educational expenditures (Kilıçaslan and Yavuz, 2019, p.301). Thus, it may be possible to spend resources for the right purposes and to ensure effectiveness in education. Education expenditures provide economic growth, increase production and ensure justice in income distribution (Tüleykan and Parlak, 2018, p.51). Considering the benefits of education to economic growth and development, the high number of the young population in Turkey makes it necessary to transfer sufficient resources to education expenditures (Egeli and Hayrullahoğlu, 2014, p.107). Investment in education is a requirement for the development of human capital. As education expenditure increases, countries' economies strengthen, and positive outcomes occur in the education of those countries (Maya, 2019, p.89).

\section{Related Research}

When the literature is examined, it is seen that although the studies dealing with the relationship between public education expenditures and academic achievements of countries in the context of comparative education have increased in recent years, they are few. In most of the studies, a positive relationship was found between education expenditures and academic achievement.

Research in the field has shown that education expenditures have a positive effect on academic achievement (Arseven, 2020, Aydin, Selvitopu and Kaya, 2018; Ceğer, 2018; Ciro and Garcia, 2017; French, French and Li, 2015; Konan, Çetin and Bozanoğlu, 2018; Toprak, Ağçakaya and Gül, 2016). In addition, it has been found that Ireland, 
Japan and South Korea (Ciro and Garcia, 2017), Estonia, Finland, Ireland, Slovak Republic, Sweden, Norway and Switzerland (Gavurova, Kocisova, Belas, and Krajcik, 2017), Poland, Slovenia and the Czech Republic (Flores, 2017), Finland, Greece and Ireland (Clement, 2002) are the countries where education expenditures are used effectively and have a positive impact on education performance. In these studies, it is understood that although there are countries that invest less and achieve better results, there are also countries that invest heavily and perform poorly. it has been understood that not only the quantity but also the efficiency of use is important in education expenditures. It has been also found that teachers' salaries, which are included in education expenditures, affect academic achievement positively (Agasisti, 2014; Akiba, Chiu, Shimizu and Liang, 2012; Gemeda and Tynjala, 2015).

On the other hand, it is seen that the studies in which the education expenditures of Turkey and other countries were analyzed (Akinci, 2017; Ayrangöl and Tekdere, 2014; Egeli and Hayrullahoğlu, 2014; Çondur and Şimşir, 2017; Işık, 2018; Kurban, 2018). In these studies, it has been found that the amount of education expenditure in Turkey has increased over the years, but this increasing rate is low when compared to OECD countries. There have been both a quantitative increase in investment in education in Turkey and an increase in achievement level in PISA cycles between 2003 and 2012. However, in the 2015 PISA, the results were not at the desired level and there was no improvement in educational outcomes despite the investments (K1lıçaslan and Yavuz, 2019; Tüleykan and Parlak, 2018).

As a result, the relevant literature shows that there are few studies dealing with the relationship between education expenditures and academic achievements of countries. However, it is understood that there is no research examining the relationship between the results of international exams such as PISA (2018) and education expenditures.

\section{Aim and Importance of the Research}

In the research, it is aimed to compare the education expenditures of Turkey and OECD countries such as Canada, Finland and South Korea, which are highly successful in the PISA 2018 cycle in terms of statistics 
and to make suggestions for Turkey. The research is important for Turkey and countries such as Canada, Finland and South Korea, which succeeded in PISA 2018, to examine education expenditures and PISA achievement situations and to identify differences and shed light on the policies and strategies that need to be developed in the Turkish education system. It is thought that comparing the current education systems by examining the education expenditures of the countries and the results of international exams will contribute to the literature.

\section{Problem Statement}

What is the relationship between Turkey and Canada, Finland and South Korea with high PISA achievement in education expenditures and academic achievement?

\section{Research Sub-Problems}

1) What is the GDP per capita in Turkey and Canada, Finland and South Korea?

2) What is the share of education in total public expenditures in Turkey and Canada, Finland and South Korea?

a) What is the public education expenditure for primary level?

b) What is the public education expenditure for secondary level?

c) What is the public education expenditure for tertiary (higher education) level?

d) What is the total public education expenditure for primary, secondary and tertiary level?

3) What is the expenditure on education levels as a percentage of GDP in Turkey and Canada, Finland and South Korea?

a) What is the share of education for primary level?

b) What is the share of education for secondary level?

c) What is the share of education for tertiary level?

d) What is the share of education in total primary, secondary and tertiary level?

4) What is the expenditure on educational institutions per a student in Turkey and Canada, Finland and South Korea?

a) What is the expenditure per student in primary level? 
b) What is the expenditure per student in secondary level?

c) What is the expenditure per student in tertiary level?

d) What is the expenditure per a student between the age of 6 and 15?

5) What are the salaries of teachers in Turkey, Canada, Finland and South Korea?

6) What are the 2018 PISA achievement levels in Turkey and Canada, Finland and South Korea, reading, mathematics and science achievement scores?

7) What is the relationship between education expenditures and 2018 PISA achievement in Turkey and Canada, Finland and South Korea?

\section{Method}

\section{Research Model}

The research is in the scanning model as it aims to make a comparative analysis of Turkey and the OECD countries of Canada, Finland and South Korea, which were successful in the PISA 2018 cycle, and Turkey in terms of education expenditures and academic achievement.

\section{Population and Sample}

The population of the research consists of 36 OECD countries. Canada, Finland and South Korea which are among the OECD countries that were successful in the 2018 PISA research and Turkey were chosen as the sample in the research. While obtaining the data, current OECD reports showing the years 2016-2017-2018 were used.

\section{Data Collection and Analysis}

The research data are taken from the 2016-2017-2018 OECD reports between the 2015 PISA cycle and the 2018 PISA cycle years. If there are reports, all years, if there are missing data, the latest year reports are considered. In the analysis of the data, the values of Canada, Finland and South Korea and the arithmetic mean of OECD countries were examined and these values were compared with Turkey's. While examining the 
education expenditures, the reports presented by the OECD showing statistics on the amount of GDP and its share in education, the share of education in public expenditures, its share in education levels, the amount of expenditure per student, and teachers' salaries were considered.

\section{Findings}

In this section, information about the GDP per capita, the share of education in public expenditures, the share of education in GDP, expenditures per student, teacher salaries and 2018 PISA achievement status in Turkey and Canada, Finland and South Korea and their comparison are given.

Findings on GDP Per Capita in Turkey and Canada, Finland and South Korea

The distribution of GDP per capita by years (2016, 2017 and 2018) in Turkey and Canada, Finland and South Korea is shown in Table 2.

Table 2. Comparison of GDP Per Capita in Turkey, Canada, Finland and South Korea (2016- 2017-2018)

\begin{tabular}{lllllll}
\hline Countries & $\begin{array}{l}\text { 2016 GDP } \\
\text { Per Capita } \\
\text { (USD) }\end{array}$ & $\begin{array}{l}\text { Ranking among } \\
\text { OECD countries } \\
\text { in 2016 (37) }\end{array}$ & $\begin{array}{l}\text { 2017 GPD } \\
\text { Per Capita } \\
\text { (USD) }\end{array}$ & $\begin{array}{l}\text { Ranking among } \\
\text { OECD countries } \\
\text { in 2017 (36) }\end{array}$ & $\begin{array}{l}\text { 2018 GPD } \\
\text { Per Capita } \\
\text { (USD) }\end{array}$ & $\begin{array}{l}\text { Ranking among } \\
\text { OECD countries } \\
\text { in 2018 (36) }\end{array}$ \\
\hline Canada & 46481 & 14 & 48623 & 14 & 50242 & 14 \\
Finland & 44930 & 15 & 47502 & 15 & 49377 & 15 \\
South Korea & 39567 & 21 & 41001 & 20 & 42240 & 20 \\
Turkey & 26693 & 34 & 28418 & 34 & 28714 & 34 \\
\multicolumn{2}{l}{ OECD Average41894 } & 18 & 43603 & 18 & 45174 & 18 \\
\hline
\end{tabular}

Source:(OECD, 2020) https://data.oecd.org/gdp/gross-domestic-product-gdp.htm

Among these selected OECD countries, the highest GDP in 2016 is Canada with 46481 dollars, the lowest is Turkey with 26693 dollars, and the OECD average is 41894 dollars. In the general ranking of OECD countries, the highest ranking is Canada as 14th, and the lowest ranking is Turkey as 34. In terms of GDP per capita, Turkey was below the OECD 
average in 2016, while Canada, Finland and South Korea were above the OECD average.

In 2017, the highest GDP is in Canada with 48623 dollars, the lowest in Turkey with 28418 dollars, and the OECD average is 43603 dollars. In the general ranking of OECD countries, the highest ranking is Canada as 14th, and the lowest ranking is Turkey as 34th. In terms of GDP per capita, Turkey was below the OECD average in 2017, while Canada, Finland and South Korea were above the OECD average.

In 2018, the highest GDP is in Canada with 50242 dollars, the lowest in Turkey with 28714 dollars, and the OECD average is 45174 dollars. In the general ranking of 37 OECD member countries, Canada is ranked as the 14th at the top and Turkey as the 34th at the bottom. It was understood that Turkey was below the OECD average in terms of GDP in 2018. As a result, it can be said that Turkey is the country with the lowest income among the selected countries in terms of GDP per capita in the three years 2016, 2017 and 2018.

Findings Regarding the Share of Education in Public Expenditures as a Percentage by Education Levels in Turkey and Canada, Finland and South Korea

The distribution regarding the comparison of the share of education in public expenditures as percentage according to education levels in Turkey and Canada, Finland and South Korea is shown in Table 3.

Table 3. Comparison of the Share of Education in Public Expenditures as a Percentage by Education Levels in Turkey and Canada, Finland and South Korea (2016)

\begin{tabular}{lllll}
\hline Countries & Primary (\%) & Secondary (\%) & Tertiary (\%) & Total (\%) \\
\hline Canada & 4.5 & 3.1 & 3.8 & 11.4 \\
Finland & 2.5 & 4.6 & 3.3 & 10.4 \\
South Korea & 4.5 & 5.5 & 2.9 & 12.9 \\
Turkey & 2.3 & 5.3 & 4.6 & 12.2 \\
OECD Average & 3.4 & 4.4 & 2.9 & 10.8 \\
\hline
\end{tabular}

Source: Table C4.1 (OECD, 2020) https://doi.org/10.1787/888933981115

It is seen that the rate of public expenditures at primary education level is $4.5 \%$ in Canada, $2.5 \%$ in Finland, $4.5 \%$ in South Korea, $2.3 \%$ in Turkey and $3.4 \%$ in OECD average. It is understood that the highest 
public expenditure is in Canada and South Korea with $4.5 \%$, and the least in Turkey with $2.3 \%$. It is understood that the rates of Turkey and Finland are below the OECD average.

In secondary education level, it is stated that Canada with $3.1 \%$, Finland with $4.6 \%$, South Korea with 5.5\%, Turkey with 5.3\% and OECD average with $3.4 \%$. It is understood that the highest rate of public education expenditure is South Korea with 5.5 and Canada with the lowest rate of $3.1 \%$. Thus, it is understood that the rates allocated to secondary education by each of the selected OECD countries -except Canada- are higher than the OECD average.

In tertiary level, it is stated that Canada with 3.8\%, Finland with 3.3\%, South Korea with $2.9 \%$, Turkey with $4.6 \%$ and OECD average with $2.9 \%$. It was observed that the highest rate was Turkey with $4.6 \%$, and the lowest rate was South Korea with $2.9 \%$. While South Korea is at the same rate as the OECD average, the rates of other selected countries are higher than the rates of OECD countries. It draws attention with Turkey's 4.6\% public expenditure rate. This situation is thought that higher education is free at state universities in Turkey and universities are supported by the state. In South Korea and Canada from other countries, it can be said that the lower rate of public expenditures in higher education and higher private student expenditures are the most important factors in the emergence of this result (MOE, 2021; Erçetin, Akbaşlı and Baysülen, 2020; Gölpek and Kavak, 2020).

In Turkey, Canada, Finland and South Korea, public expenditures in the total of primary, secondary and tertiary levels are seen to be Canada with $11.4 \%$, Finland with $10.4 \%$, South Korea with $12.9 \%$, Turkey with $12.2 \%$ and OECD average with $10.8 \%$. It is understood that the highest rate is South Korea with $12.9 \%$ and the lowest rate is Finland with $10.4 \%$.

When the rates of public expenditures on education are considered, it is seen that Turkey, Canada, Finland and South Korea countries make higher public expenditures than the general average of OECD countries. Although Turkey's public expenditure rate is higher than the average rate of OECD countries, it could not achieve success in 2018 PISA such as Canada, Finland and South Korea. 
Findings Regarding the Share of Education in GDP as a Percentage by Education Levels in Turkey and Canada, Finland and South Korea

The distribution regarding the comparison of the share of education in GDP as a percentage according to education levels in Turkey and Canada, Finland and South Korea is shown in Table 4.

Table 4. Comparison of the Share of Education in GDP as a Percentage by Education Levels in Turkey and Canada, Finland and South Korea (2016)

\begin{tabular}{lllll}
\hline Countries & Primary $(\%)$ & Secondary $(\%)$ & Tertiary $(\%)$ & Total $(\%)$ \\
\hline Canada & 2.1 & 1.5 & 2.3 & 5.9 \\
Finland & 1.4 & 2.5 & 1.7 & 5.5 \\
South Korea & 1.6 & 2.1 & 1.7 & 5.4 \\
Turkey & 1.0 & 2.5 & 1.9 & 5.4 \\
OECD Average & 1.5 & 2.0 & 1.5 & 5.0 \\
\hline
\end{tabular}

Source: Table C2.1 (OECD, 2020) https://doi.org/10.1787/888933981077

Among the selected countries, it is understood that the highest rate of education expenditures in GDP at primary education level is Canada with $2.1 \%$, and the lowest rate is Turkey with $1 \%$. It is seen that the highest rate in secondary education is Finland and Turkey with $2.5 \%$, and the lowest rate is Canada with $1.5 \%$. It is understood that the highest rate in higher education level is Canada with $2.3 \%$, the lowest rate is Finland and South Korea with $1.7 \%$. The share of education in GDP of all countries included in the research is higher than OECD countries. When the shares of education in GDP are analyzed by education levels in Turkey, Canada, Finland and South Korea in the total of primary, secondary and tertiary levels, it is understood that the highest rate is Canada with 5.9\%, the lowest rate is South Korea and Turkey with $5.4 \%$. It is seen that the average share of education in the GDP of OECD countries is $5 \%$. It is noteworthy that Turkey, whose total expenditure on educational institutions as a percentage of GDP is higher than the average of OECD countries such as Canada, Finland and South Korea, which were successful in the PISA 2018 cycle, was not as successful in 2018 PISA as other countries. 
Findings on Expenditures per Student in Turkey and Canada, Finland and South Korea

The distribution of per-student expenditure in Turkey and Canada, Finland and South Korea by education levels is shown in Table 5.

Table 5. Comparison of Expenditures per Student by Education Levels in Turkey, Canada, Finland and South Korea (2016)

\begin{tabular}{llllll}
\hline Countries & $\begin{array}{l}\text { Primary } \\
\text { (USD) }\end{array}$ & $\begin{array}{l}\text { Secondary } \\
\text { (USD) }\end{array}$ & $\begin{array}{l}\text { Tertiary } \\
\text { (USD) }\end{array}$ & $\begin{array}{l}\text { Expenditure } \\
\text { between the age of } \\
\mathbf{6} \text { and 15 (USD) } \\
\text { between the age of 6 } \\
\text { and 15 (35) }\end{array}$ \\
\hline Canada & 9207 & 13856 & 23700 & 110668 & 12 \\
Finland & 9447 & 10427 & 17541 & 112767 & 9 \\
South Korea & 11029 & 12370 & 10486 & 113717 & 8 \\
Turkey & 4168 & 4659 & 10519 & 43351 & 34 \\
OECD Average & 8470 & 9968 & 15556 & 92674 & \\
\hline
\end{tabular}

Source: Table C1.1; Figure C1.3 (OECD, 2020) https://doi.org/10.1787/888933981058

It is seen that the highest amount of expenditure per student at primary education level is South Korea with 11029 dollars, the lowest is Turkey with 4168 dollars, and the OECD average is 8470 dollars. It is understood that Turkey's expenditures per student are below the OECD average.

In the secondary education level, the highest amount is Canada with 13586 dollars, and the lowest amount is Turkey with 4659 dollars. The OECD average was determined as 9968 dollars. While other countries spend above the OECD average, Turkey spends below the OECD average.

It is understood that the highest amount in the tertiary level is Canada with 23700 dollars, the least amount is South Korea and the OECD average is 15556 dollars. While Canada and Finland spend above the OECD average, Turkey and South Korea spend below the OECD average.

When the total expenditures for the 6-15 age group are ranked from the highest to the lowest: South Korea with 113717 dollars, Finland with 112767 dollars, Canada with 110668 dollars and Turkey with 43351 dollars. While Turkey spends on the 6-15 age group below the OECD average, Canada, Finland and South Korea spend above the OECD 
average. According to OECD data, among 35 countries, South Korea ranks 8th, Finland 9th, Canada 12th and Turkey 34th.

It is noteworthy that while the amount of expenditure per student in education increases gradually from primary to tertiary in Turkey, Canada, Finland and the OECD average, it decreases in South Korea. In South Korea, the amount of expenditure per student is mostly in secondary and primary education, and the least in higher education. In other countries, the situation is the opposite.

Findings on Teacher Salary in Turkey and Canada, Finland and South Korea

The distribution regarding the comparison of the salaries of teachers with 15 years of experience in Turkey and Canada, Finland and South Korea is shown in Table 6.

Table 6. Comparison of Salaries of Teachers with 15 Years of Experience in Turkey and Canada, Finland and South Korea

\begin{tabular}{llllll}
\hline \multicolumn{1}{c}{ Countries } & 2016 (USD) & $\mathbf{2 0 1 7}$ (USD) & $\begin{array}{l}\text { Ranking } \\
\text { OECD countries in2018 (USD) } \\
\text { 2017 (32) }\end{array}$ & \begin{tabular}{l} 
Ranking $\begin{array}{l}\text { among } \\
\text { OECD countries in } \\
\text { 2018 (33) }\end{array}$ \\
\hline Canada
\end{tabular} \\
Finland & $\mathrm{m}$ & 65475 & 3 & 67301 & 3 \\
South Korea & $\mathrm{m}$ & 40991 & 17 & 42180 & 18 \\
Turkey & $\mathrm{m}$ & 53405 & 8 & 57179 & 9 \\
OECD Average & $\mathrm{m}$ & 28835 & 26 & 28545 & 27 \\
\hline
\end{tabular}

m: Missing data, data for those years are not available in OECD reports.

Source: Table D3.1 (OECD, 2020) https://doi.org/10.1787/888933981229, (OECD, 2020) https://data.oecd.org/teachers/teachers-salaries.htm

When teachers' incomes are ranked from highest to lowest in 2017; Canada with 65475 dollars, South Korea with 53405 dollars, Finland with 40991 dollars and Turkey with 28835 dollars. Among the 32 countries in the OECD data, when teachers' salaries are ranked from the highest to the lowest; Canada ranks 3rd, South Korea 8th, Finland 17th, and Turkey 26th.

When the income of the teachers in 2018 is analyzed, the ranking from the highest to the lowest is; Canada with 67301 dollars, South Korea with 57179 dollars, Finland with 42180 dollars and Turkey with 28545 dollars. 
The average income of teachers in OECD countries is 45947 dollars. While the income of teachers in Canada and South Korea in 2018 is above the OECD average, it is understood that the income of teachers in Turkey and Finland is below the OECD average. Among the 33 countries in the OECD data, when teachers' salaries are ranked from the highest to the lowest; Canada ranks 3rd, South Korea 9th, Finland 18th, and Turkey 27 th.

The distribution of starting teachers' salaries and the salaries of teachers with 15 years of experience in Turkey and Canada, Finland and South Korea is shown in Table 7.

Table 7. Comparison of Starting Teachers' Salaries and Teachers' Salaries with 15 Years of Experience in Turkey, Canada, Finland and South Korea (Primary Level)

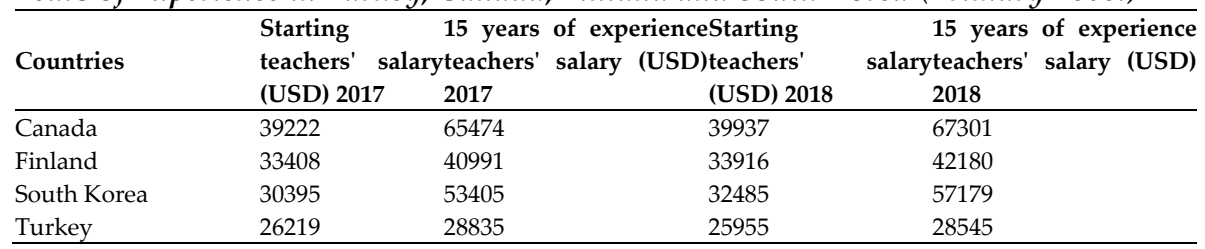

Source: (OECD, 2020) https://data.oecd.org/teachers/teachers-salaries.htm

The annual incomes of starting teachers and teachers with 15 years of experience in Turkey, Canada, Finland and South Korea for the years 2017 and 2018 are shown. While the income of teachers increases significantly as experience increases in Canada, Finland and South Korea, the increase between starting teachers and teachers with 15 years of experience is very limited in Turkey. While teacher experience is given importance in Canada, Finland and South Korea, it is thought that teacher experience is not given much importance in Turkey.

\section{Findings on 2018 PISA Achievement Status in Turkey and Canada, Finland and South Korea}

The distribution regarding the comparison of 2018 PISA achievement rates in Turkey and Canada, Finland and South Korea is shown in Table 8 . 
Table 8. Comparison of 2018 PISA Achievement Situations in Turkey and Canada, Finland and South Korea (2018)

\begin{tabular}{|c|c|c|c|c|c|c|}
\hline Countries & $\begin{array}{l}\text { Reading } \\
\text { Score }\end{array}$ & $\begin{array}{l}\text { Reading } \\
\text { Ranking in } \\
\text { OECD } \\
\text { Countries (36) }\end{array}$ & $\begin{array}{l}\text { Mathematics } \\
\text { Score }\end{array}$ & $\begin{array}{l}\text { Mathematics } \\
\text { Ranking in } \\
\text { OECD Countries } \\
\text { (37) }\end{array}$ & $\begin{array}{l}\text { Science } \\
\text { sScore }\end{array}$ & $\begin{array}{l}\text { Science } \\
\text { Ranking in } \\
\text { OECD } \\
\text { Countries } \\
(37)\end{array}$ \\
\hline$\overline{\text { Canada }}$ & 520 & 2 & 512 & 7 & 518 & 5 \\
\hline Finland & 520 & 3 & 507 & 11 & 522 & 3 \\
\hline South Korea & 514 & 5 & 526 & 2 & 519 & 4 \\
\hline Turkey & 466 & 31 & 454 & 33 & 468 & 30 \\
\hline OECD Average & 487 & & 489 & & 489 & \\
\hline
\end{tabular}

Source: PISA 2018 Türkiye Ön Raporu, 2019,

(OECD, 2020) https://PISAdataexplorer.oecd.org/ide/idePISA/

Canada ranked 2nd in Reading, 7th in Mathematics, and 5th in Science in 2018 PISA among OECD countries. Finland ranked 3rd in Reading, 11th in Mathematics, and 3rd in Science among OECD countries in 2018 PISA. South Korea ranked 5th in Reading, 2nd in Mathematics, and 4th in Science among OECD countries in 2018 PISA. Turkey, on the other hand, ranked 31st in Reading, 33rd in Mathematics, and 30th in Science among OECD countries in 2018 PISA, and scored below the OECD average in all score types.

When the results of PISA 2018 are examined, it is seen that, as in the 2015 PISA cycle, Canada is among the most successful countries in the American continent, South Korea in the Asian continent, and Finland in the European continent. Turkey, on the other hand, achieved scores below the OECD average and could not show the desired success.

\section{Findings on Education Expenditures and 2018 PISA Achievement Status in Turkey and Canada, Finland and South Korea}

Information on the comparison of 2018 PISA academic achievement status, GDP, student expenditures and teacher salaries in Turkey and Canada, Finland and South Korea is shown in Table 9. 
Table 9. Comparison of GDP, Student Expenditures, Teacher Salaries and 2018 PISA Academic Achievement in Turkey and Canada, Finland and South Korea

\begin{tabular}{lllll}
\hline Countries & $\begin{array}{l}\text { GDP Ranking } \\
\text { (2016-17-18) (36 } \\
\text { countries) }\end{array}$ & $\begin{array}{l}\text { Ranking of expenditure Teacher salary } \\
\text { per a student aged 6-15 } \\
\text { (2016) (35 countries) }\end{array}$ & $\begin{array}{l}\text { PISA 2018 Reading } \\
\text { (33 countries) }\end{array}$ & $\begin{array}{l}\text { Score Ranking (36 } \\
\text { countries) }\end{array}$ \\
\hline Canada & 14 & 12 & 3 & 2 \\
Finland & 15 & 9 & 18 & 3 \\
South Korea & 20 & 8 & 9 & 5 \\
Turkey & 34 & 34 & 28 & 31 \\
\hline
\end{tabular}

When the average of 2016, 2017 and 2018 is taken in the GDP ranking, it is seen that Canada ranks 14th, Finland 15th, South Korea 20th and Turkey 34th among 36 countries in GDP per capita ranking. Since data for 2017 and 2018 could not be accessed for the expenditure ranking of students (6-15 age range), only 2016 OECD data were obtained. In terms of expenditure per student, South Korea ranks 8th, Finland 9th, Canada 12th, and Turkey 34th among 35 countries.

Among 33 countries in the ranking of teacher salaries; Canada ranks 3rd, South Korea 9th, Finland 18th and Turkey 28th. In the calculations of teacher salaries, the accounts of primary school teachers with 15 years of experience were considered.

Since the reading is determined as the major domain of assessment in the PISA 2018 cycle, only the reading was considered. Among 36 countries in the PISA 2018 Reading Ranking; Canada is at the 2nd, Finland is at the 3rd, South Korea is at the 5th and Turkey is at the 31st.

There are differences in GDP, expenditure per student, teacher salaries and reading scores between Turkey and selected OECD countries (Canada, South Korea and Canada), which are the successful countries in the PISA 2018. When these data are considered, it is seen that if the GDP, the amount of expenditure per student and teacher salaries are effectively used, it is likely to achieve success. However, it is very difficult to say that spending more on education is the definitive solution for success. For example, Canada ranked 12th in expenditure per student, and South Korea ranked 8th, but Canada ranked 2nd, South Korea ranked 5th in reading. 


\section{Discussion}

Education provides significant benefits not only to the individual getting education, but also to the country and society (Çondur and Şimşir, 2017, p.51). As educated individuals develop, that country and society develop. Education has a positive effect on economic development. Although economic development is seen as an increase in income, education expenditures are also seen as an important indicator of economic development (Ayrangöl and Tekdere, 2014, p.6). When education expenditures are used effectively, they contribute to economic growth and development. Akıncı (2017) found that education expenditures positively affect economic growth in the short and long term. He stated that investment in education and therefore education expenditures increase the welfare level of people.

Aristovnik (2011), in his research on the efficiency of education expenditures, found Japan, Korea and Finland as the most productive and successful countries in the field of education sector. Among OECD countries, the performance of Finnish students shows positive results above expectations according to the level of education expenditures. Of course, the effective success of an education system does not depend only on spending (Kupiainen, Hautamaki and Karjalainen, 2009, p.43). Finland prioritizes teacher quality in order to use education expenditures effectively. Some of the lessons to be learned from PISA that make a school successful in Finland include prioritizing spending on improving teacher quality (Lewis, 2020, p.138). It is thought that academic success in PISA will increase when education expenditures are increased and used effectively, just like in successful countries shown in this example.

A prominent feature of the South Korean education system is the high quality of teachers who are carefully selected, supported and rewarded. Not only have they invested in teachers' salaries, but they have also invested in teacher training and an effective recruitment system for teachers. Thus, they achieved better than expected performance in education expenditures per student (OECD, 2014). South Korea, which uses education expenditures effectively, continues to be among the leading countries in PISA. 
Canada invests significant public resources in the provision of education. Canadian people are deeply concerned with the quality of education offered in schools (Council of Ministers of Education, 2021). Canada shows its commitment to education with its high expenditures on education. The Canadian government gives great importance to education and continues to invest in education. In the research covering the years 2013 to 2018 in Canada, a significant increase was observed in the expenditures per student in public schools (Hill, Li and Emes, 2021, p.19). These education expenditures showed a positive effect on the PISA scores.

According to the results of the research, it has been seen that education expenditures have a positive effect on academic achievement. Arseven (2020); Aydın et al., (2018); Ceğer (2018); Konan et al., (2018); Ciro and Garcia, (2017); French et al., (2015); Flores, (2017); Gavurova et al. (2017); Toprak et al., (2016) found in their research that education expenditures positively affect academic achievement. In this research, it has been determined that Turkey's expenditures per student are below the OECD average. Ayrangöl and Tekdere (2014), Egeli and Hayrullahoğlu (2014) also stated in their research that expenditures per student in Turkey are below the OECD average. While there is a difference in favor of experienced teachers when comparing experienced teachers and starting teachers in countries that are successful in PISA in terms of their salaries, this difference is very small in Turkey. Akiba et al. (2012); Aydin et al. (2018) and Işık (2018) reached the same results in their research.

\section{Conclusion and Recommendations}

In terms of the Gross Domestic Product (GDP) variable, it was found that the GDP amount of Canada, Finland and South Korea is higher than the OECD average, while the GDP amount of Turkey is low. In addition, Canada, Finland and South Korea are ranked higher in the overall GDP ranking, while Turkey is at the bottom.

In terms of public expenditures on education, Turkey and Canada, Finland and South Korea all have higher public expenditures than the general average of OECD countries. It is noteworthy that Turkey's public 
expenditures on education at the tertiary level are higher than those of Canada, Finland and South Korea. It can be said that it is because state universities are offered to students free of charge in Turkey. Although the rate of public expenditures on tertiary in Turkey is higher than other selected countries, it could not achieve success in 2018 PISA such as Canada, Finland and South Korea.

Considering the percentage of education in GDP; The percentage of education in Turkey (GDP) is higher than the OECD average, as are the countries that were successful in the PISA 2018 cycle, such as Canada, Finland and South Korea. However, although Turkey's percentage of GDP allocated to education is above the OECD average, Turkey cannot allocate as much money as the countries of Canada, Finland and South Korea, since the amount of GDP is less than other countries. For this reason, especially in countries with limited opportunities, such as Turkey, education expenditures should be effective and its results should be evaluated well and spent in the right place at the right time.

While Canada, Finland and South Korea countries are above the OECD averages in expenditures per student at all educational levels, they are below Turkey. According to OECD data, South Korea, Finland and Canada are at the top of the expenditure rankings among 35 countries, while Turkey is at the bottom. It has been observed that Turkey's expenditures are almost 3 times less than South Korea, Finland and Canada in expenditures for the 6-15 age group. It can be said that there is a positive relationship between PISA achievement and education expenditures.

According to teacher salaries, Canada, Finland and South Korea are above the OECD averages, while Turkey is below. It has been found that Turkey is one of the countries with the lowest teacher salaries among OECD countries. When the salaries of the starting and 15 years experienced teachers are compared; In Canada, Finland and South Korea, it is seen that incomes increase significantly as the years of experience increase, while the increase between the starting teacher and the experienced teacher in Turkey is quite limited. It is thought that while teacher experience is given importance in countries that are successful in PISA, it is not given much importance in Turkey. This 
situation reduces the professional motivation of teachers. This result is compatible with the studies of Aydın et al., (2018) and Işık (2018).

As a result, Turkey does not get good results in student outcomes in international exams. There were significant differences in GDP, expenditure per student, teacher salaries and PISA success between Turkey and selected OECD countries (Canada, South Korea and Canada), which are among the successful countries in PISA 2018. It is seen that the success of PISA is also high in countries with a high economic share allocated to education. However, it is very difficult to say that spending more on education is the definitive solution for success. There are many factors to ensure success in education.

Education is the future of a country. Politicians should prioritize education and facilitate their people's access to quality education. Educational outcomes may not yield results in the short run, but in the long run, they can keep a country afloat for years and optimize the welfare of its people. While deciding how to make education expenditures, managers should be so careful. Resources allocated to education should be used effectively and the results should be monitored. If the quality of education expenditures is given importance rather than the quantity, more benefits can be achieved with less cost. Social justice should be considered in education investments, and priority should be given to the regions that really need them.

Politicians, school administrators, teachers, parents and students must be diligent in fulfilling their educational responsibility in order to achieve successful results in international exams. When determining policies regarding education investments, good investment models should be used by making cost-benefit analysis.

\section{References}

Agasisti, T. (2014). The efficiency of public spending on education: An empirical comparison of EU countries. European Journal of Education, 49(4), 543-557.

Akıncl, A. (2017). Türkiye'de eğitim harcamalarının ekonomik büyüme üzerindeki etkisi. Maliye Dergisi, 173, 387-397. 
Akiba, M., Chiu, Y-F., Shimizu, K. and Liang, G. (2012). Teacher salary and national achievement: A cross-national analysis of 30 countries. International Journal of Educational Research, 53, 171-181.

Aristovnik, A. (2011). An analysis of the efficiency of education spending in central and eastern Europe. Management, Knowledge and Learning International Conference 2011, Slovenia.

Arseven, İ. (2020). Türkiye'de eğitim ve ekonomi. A. Arseven ve İ. Arseven (Der.), Türk eğitim sistemi farklı ülkelerle karşllaştırmalı içinde (p.181205). Ankara: Anı yayınclik.

Aydın, A., Selvitopu, A. and Kaya, M. (2018), Eğitime yapılan yatırımlar ve PISA 2015 sonuçları: Karşılaştırmalı bir inceleme. İlköğretim Online, 17(3), 1283-1301.

Ayrangöl, Z. and Tekdere, M. (2014). Türkiye ve OECD ülkelerinde yapılan eğitim harcamalarının karşılaştırmalı analizi. Lefke Avrupa Univiversitesi Sosyal Bilimler Dergisi, 5(2), 1-30.

Ceğer, B. (2018). OECD ülkeleri ile Türkiye eğitim harcamalarının karşılaştırılması. (Yayımlanmamış yüksek lisans tezi). Hacettepe Üniversitesi, Eğitim Bilimleri Bilimler Enstitüsü, Ankara

Ciro, J. A. and Garcia, A. T. (2018). Economic efficiency of public secondary education expenditure: How different are developed and developing countries. Primer Semester, 80, 119-154.

Clements, B. (2002). How efficient is education spending in Europe. European Review of Economics and Finance, 1, 3-26.

Council of Ministers of Education, Canada (2021). Programme for international student assessment (PISA). https://www.cmec.ca/251/Programme_for_International_Student_Assessme nt_(PISA).html (Accessed on 15.05.2021).

Çondur, F. and Cömertler-Şimşir, N. (2017). Türkiye'de eğitim harcamaları, ekonomik büyüme ve genç işsizlik ilişkilerinin analizi. Uluslararası Bilimsel Araştırmalar Dergisi, 2(6), 44-59.

Education 2030-4, (2016). Incheon declaration and framework for action for the implementation of sustainable development goal 4 . https://unesdoc.unesco.org/ark:/48223/pf0000245656___(Accessed on 22.02.2021).

Egeli, H. and Hayrullahoğlu, B. (2014). Türkiye ve OECD ülkelerinde eğitim harcamalarının analizi. Finans Politik and Ekonomik Yorumlar, 51(593), 93-108. 
Erçetin, Ş. Ş., Akbaşlı, S. and Baysülen, E., (2020). Devletin yükseköğretim öğrencilerine yönelik yaptı̆̆ karşılıksız harcamalarının mali boyutu. OPUS-Uluslararası Toplum Araştırmaları Dergisi, 16(28), 1183-1199. DOI: 10.26466/opus.680225.

Flores, I. (2017). Modelling efficiency education. Sociologia, 83, 157-170.

French, J. J., French, A. and Li, W. (2015). The relationship among cultural dimensions, education expenditure, and PISA performance. International Journal of Educational Development, 42, 25-34.

Gavurova, B., Kocisova, K., Belas, L. and Krajcik, V. (2017). Relative efficiency of government expenditure on secondary education. Journal of International Studies, 10(2), 329-343.

Gemeda, F. T. and Tynjala, P. (2015). Exploring teachers' motivation for teaching and professional development in Ethiopia: Voices from the field. Journal of Studies of Education, 5(2), 169-186.

Gölpek, F. and Kavak, O. (20220). Yükseköğretimde bir finansman politikası. International Black Sea Coastline Countries Symposium , 4, 159-169.

Hill, T., Li, N. and Emes, J. (2021). Education Spending in Public Schools in Canada. Fraser Institute. https://www.fraserinstitute.org/sites/default/files/education-spending-inpublic-schools-in-canada-2021.pdf (Accessed on 15.05.2021).

Işık, S. (2018). Yatırım carilerin Türkiye'nin küresel rekabet gücü üzerindeki etkileri. (Yayımlanmamış doktora tezi). Uludağ Üniversitesi, Sosyal Bilimler Enstitüsü, Bursa.

Kılıçaslan, H. and Yavuz, H. (2019), PISA sonuçları ile Türkiye'de eğitim harcamaları ilişkisi. Bilgi, 21(2), 296- 319.

Konan, N., Çetin, R. B. and Bozanoğlu, B. (2018). PISA'da başarılı olan ülkelerin eğitim finansmanının uluslararası göstergeler ışığında analizi. Scientific Educational Studies, 2(1), 56-70.

Kupiainen, S., Hautamaki J. and Karjalainen, T. (2009). The Finnish education system and PISA. Helsinki: Ministry of Education Publications.

Kurban, S. (2018). OECD Bir bakışta eğitim raporu 2017 bağlamında Türkiye'de finans ve insan kaynakları yatırımlarının değerlendirilmesi. Akademik Sosyal Araştırmalar Dergisi, 6(68), 437-452.

Lewis, S. (2020). PISA, Policy and the OECD respatialising global educational governance through PISA for schools. Singapore: Springer Nature Singapore Pte Ltd. 
Lonescu, D. D., Lonescu, A. M. and Jaba, E. (2013). The investments in education and quality of life. Scientific Papers, Special Issue (December), 141-158.

Maya, İ. (2019). Gelişmekte olan ülkelerde eğitim politikaları. Ankara: Pegem Akademi.

MEB. (2019). PISA 2018 Türkiye ön raporu, http://www.meb.gov.tr/meb_iys_dosyalar/2019_12/03105347_PISA_2018_ Turkiye_On_Raporu.pdf. (Accessed on 15.01.2021).

MOE. (2021). Korean education system, higher education. http://english.moe.go.kr/sub/info.do? $\mathrm{m}=020105$ ands=english. (Accessed on 18.06.2021).

OECD (2014), Lessons from PISA for Korea, strong performers and successful reformers in education. OECD Publishing. http://dx.doi.org/10.1787/9789264190672-en. (Accessed on 14.05.2021).

OECD (2019a). Education at a glance 2019: OECD Indicators, OECD Publishing, Paris. https://doi.org/10.1787/f8d7880d-en, (Accessed on 21.05.2021).

OECD (2019b), PISA 2018 assessment and analytical framework, PISA, OECD Publishing, Paris. https://doi.org/10.1787/b25efab8-en, (Accessed on 21.06.2021).

OECD (2020), OECD Statistics. https://stats.oecd.org, (Accessed on 05.12.2020). Özen, H. (2020). Dromokratik çağda eğitim ve okulun açmazları: Paul Virilioik açıdan analojik bir çözümleme. OPUS-Uluslararası Toplum Araştırmaları Dergisi, 16(Eğitim ve Toplum Özel Sayısı), 6437-6459. DOI: 10.26466/opus.724349.

Toprak, D., Ağcakaya, S. E. and Gül, H. (2016). Sosyal devlet yaklaşımı açısından Türkiye'de 1980 sonrası eğitim harcamalarının analizi. Dokuz Eylül Üniversitesi İktisadi İdari Bilimler Fakültesi Dergisi, 31(1), 123-165.

Tüleykan, H. and Parlak, M. A. (2018). Türkiye'de kamu kesiminin eğitim harcamalarının değerlendirilmesi. Uluslararası Yönetim Ĕ̆itim ve Ekonomik Perspektifler Dergisi, 6(2), 34-53.

UNESCO, (2020). Education transforms lives, https://en.unesco.org/themes/education (Accessed on 15.05.2020). 


\section{Citation Information}

Maya, İ. ve Yakut, S. (2021). Comparison of Turkey and countries with high PISA achievement in terms of education expenditures and academic achievements. OPUS- International Journal of Society Studies, 18(43), 6195-6219. DOI: 10.26466/opus.957777. 